\title{
Outbreak
}

\section{Coronavirus respiratory illness in Saudi Arabia}

\author{
Mohammed N. Al-Ahdal ${ }^{1}$, Ahmed A. Al-Qahtani ${ }^{1,2}$, Salvatore Rubino ${ }^{3}$ \\ ${ }^{1}$ Department of Infection and Immunity, King Faisal Specialist Hospital and Research Centre, Riyadh, Saudi Arabia \\ ${ }^{2}$ Liver Disease Research Center, King Saud University, Riyadh, Saudi Arabia \\ ${ }^{3}$ Dipartimento di Scienze Biomediche, Università degli Studi di Sassari, Sassari, Italy
}

\begin{abstract}
Although viruses that belong to the coronavirus family are known since the 1930s, they only gained public health attention when they were discovered to be the causative agent of the severe acute respiratory syndrome (SARS) outbreak in China in 2002-2003. On 22 September 2012, the Ministry of Health (MOH) in Saudi Arabia announced the detection of what was described as a "rare pattern" of coronavirus respiratory infection in three individuals, two Saudi citizens and one person from the Gulf Region. Neither Saudi citizen survived the infection. Molecular analysis of the isolates showed that the virus belongs to the genus beta-coronavirus. It is not known if the new isolates are circulating in the population or has recently diverged. The emergence of these novel isolates that resulted in fatal human infection ascertains that health authorities all over the world must be vigilant for the possibility of new global pandemics due to novel viral infection.
\end{abstract}

Key words: Coronavirus, Saudi Arabia, Respiratory disease, Hajj Season

J Infect Dev Ctries 2012; 6(10):692-694.

(Received and Accepted 17 October 2012)

Copyright $(C 2012$ Al-Ahdal et al. This is an open-access article distributed under the Creative Commons Attribution License, which permits unrestricted use, distribution, and reproduction in any medium, provided the original work is properly cited.

On 22 September 2012, the Ministry of Health $(\mathrm{MOH})$ in Saudi Arabia announced that two Saudi individual have died from clinical complications associated with an infection of a rare pattern of coronavirus [1].

The emergence of the SARS CoV virus, the causative agent of Severe Acute Respiratory Syndrome (SARS) infection [2,3] in 2002-2003, is still a fresh reminder that modern air travel can bring an epidemic to any city in a matter of days or weeks. Official records from the World Health Organization (WHO) registered 8,422 SARS cases with 916 deaths and a mortality of approximately $10 \%$ [4]. Fortunately the last confirmed case of SARS CoV was identified in China in May 2004 [5].

The first Saudi case of coronavirus in the current outbreak was identified in Jeddah from the sputum of a 60 -year-old male Saudi patient with pneumonia. The virus was identified by using Vero and Rhesus Monkey Kidney Epithelial (LLC-MK2) cell culture lines. This work was performed at the Virology Laboratory of Dr Soliman Fakeeh Hospital [6]. The case was confirmed in Rotterdam, The Netherlands, where the virus was sequenced at the Erasmus Medical Centre (EMC) in a collaborative study (GenBank accession number: JX869059, termed hCoV-EMC)
[7]. The patient died from acute renal failure in June 2012, some days after admission to the hospital.

No clinical information is available regarding the other Saudi patient who also died [1].

The second confirmed case due to the novel coronavirus was a 49-year-old male of Qatari nationality. The patient had a recent travel history to Saudi Arabia from 31 July 2012 to 18 August 2012, prior to onset of illness on 3 September 2012, when he reported a mild respiratory illness that became severe six days later with the development of bilateral pneumonia. The patient was admitted with acute respiratory symptoms to an intensive care unit (ICU) in Doha, Qatar, and then transferred to the United Kingdom when his condition worsened. The coronavirus was isolated at the Health Protection Agency in London [8]. According to Pebody and coworkers [9], who studied the clinical case in detail, the patient acquired the virus in Qatar. This assertion was made on the basis of the time course of the patient's infection. However, molecular analysis of the PCR amplicon product of the Qatari patient showed a sequence very closely related to that of the hCoVEMC detected in the patient from Saudi Arabia, which belongs to the genus beta-coronavirus, that is closely related to bat coronaviruses [10]. Reports of new 
variants of coronavirus that might be harbored in bats and may have the potential of being transmitted to animals and humans have recently been made [11].

A new diagnostic tool based on a real-time reverse-transcription polymerase chain reaction assays suitable for qualitative and quantitative detection of this new infective agent is now available for Public Health purposes [12]. Coronoviridae is a family of viruses containing a large number of variants, some of which cause common cold respiratory diseases to humans that are self-limiting. Some, such as SARS, may prove to be pathogenic and infectious $[13,14]$. Previously in Saudi Arabia, only the Netherlands human coronavirus (HCoV-NL63) had been isolated from children with respiratory tract infections [15], and an outbreak of severe respiratory illness of unknown etiology was reported by the Ministry of Health in Jordan earlier in 2012 [16]. This new virus, however, is different from those identified in humans in the past. Further studies are necessary to determine whether the novel coronavirus was circulating in the population in the Middle East Region or if it is a recent acquisition. Furthermore, it will be crucial to identify the origin for this novel virus. The World Health Organization is currently actively seeking further information on this variant of coronavirus to assess the local and global public health implications of this infection.

From a Public Health point of view, serious attention should be paid to the surveillance of influenza-like illnesses in the Middle East region, as the extremely crowded Hajj (pilgrimage to Makkah) season is starting. Hundreds of thousands of individuals from all walks of life are now pouring into the Holy Places in Saudi Arabia (Makkah and Madinah) through the City of Jeddah, where at least one of the cases was identified. The Saudi MOH has assured the public that such occurrences are rare and the overall health conditions are "reassuring and do not cause concern" [17]. Personal hygiene and vaccinetaking must be observed in general for several infectious diseases as advised by the WHO and the Saudi MOH [18].

\section{References}

1. Ministry

News

(2012)

http://www.moh.gov.sa/en/Ministry/MediaCenter/News/Page s/news-2012-09-22-001.aspx. Last accessed 10 October 2012.

2. Peiris JS, Yuen KY, Osterhaus AD, Stohr K (2003) The severe acute respiratory syndrome. N Engl J Med 349: 24312441.

3. Xing W, Hejblum G, Leung GM, Valleron AJ (2010) Anatomy of the epidemiological literature on the 2003 SARS outbreaks in Hong Kong and Toronto: a time-stratified review. PLoS Med 7: e1000272.

4. World Health Organization (2003) WHO final summary SARS, 15 August 2003: Summary table of SARS cases by country, 1 November 2002 - 7 August 2003. Available from: http://www.who.int/csr/sars/country/2003_08_15/en/index.ht $\mathrm{ml}$. Last accessed 10 October 2012.

5. World Health Organization. Global Alert and Response (GAR) (2004) China's latest SARS outbreak has been contained, but biosafety concerns remain - Update 7, 18 May 2004.

http://www.who.int/csr/don/2004_05_18a/en/index.html. Last accessed 10 October 2012.

6. ProMED-mail (2012) Novel coronavirus - Saudi Arabia: human isolate. Archive Number: 20120920.1302733. Available from: http://www.promedmail.org/direct.php?id=20120920.130273 3. Last accessed 10 October 2012.

7. van Boheemen S, Zaki AM, Bestebroer TM, de Graaf M, Victor S, Osterhaus AD, Haagmans BL, Fouchier RA. Genomic Analysis for a Newly Isolated Human Betacoronavirus Lineage 2C. Genbank: Human betacoronavirus 2c EMC/2012, complete genome, 30,118 bp linear RNA, Accession: JX869059.1 GI: 407076736 [external link]. Last accessed 10 October 2012.

8. Health Protection Agency (2012) Acute respiratory illness associated with a new virus identified in the UK 23 September 2012. http://www.hpa.org.uk/NewsCentre/NationalPressReleases/20 12PressReleases/120923acuterespiratoryillnessidentified/.

Last accessed 10 October 2012.

9. Pebody RG, Chand MA, Thomas HL, Green HK, Boddington NL, Carvalho C, Brown CS, Anderson SR, Rooney C, Crawley-Boevey E, Irwin DJ, Aarons E, Tong C, Newsholme W, Price N, Langrish C, Tucker D, Zhao H, Phin N, Crofts J, Bermingham A, Gilgunn-Jones E, Brown KE, Evans B, Catchpole M, Watson JM (2012) The United Kingdom public health response to an imported laboratory confirmed case of a novel coronavirus in September 2012. Euro Surveill 17: pii=20292. Available online: http://www.eurosurveillance.org/ViewArticle.aspx?ArticleId= 20292. Last accessed 10 October 2012.

10. Bermingham A, Chand MA, Brown CS, Aarons E, Tong C, Langrish C, Hoschler K, Brown K, Galiano M, Myers R, Pebody RG, Green HK, Boddington NL, Gopal R, Price N, Newsholme W, Drosten C, Fouchier RA, Zambon M (2012) Severe respiratory illness caused by a novel coronavirus, in a patient transferred to the United Kingdom from the Middle East, September 2012. Euro Surveill.17: pii=20290. Available online:

http://www.eurosurveillance.org/ViewArticle.aspx?ArticleId= 20290. Last accessed 10 October 2012.

11. Balboni A, Battilani M, Prosperi S (2012) The SARS-like coronaviruses: the role of bats and evolutionary relationships with SARS coronavirus. New Microbiol 35: 1-16.

12. Corman VM, Eckerle I, Bleicker T, Zaki A, Landt O, Eschbach-Bludau M, van Boheemen S, Gopal R, Ballhause M, Bestebroer TM, Muth D, Müller MA, Drexler JF, Zambon M, Osterhaus AD, Fouchier RM, Drosten C (2012) Detection of a novel human coronavirus by real-time reversetranscription polymerase chain reaction. Euro Surveill 17: pii=20285. Available online: 
http://www.eurosurveillance.org/ViewArticle.aspx?ArticleId= 20285. Last accessed 10 October 2012.

13. World Health Organization Global Alert and Response (GAR) (2012) Revised interim case definition - novel coronavirus.

http://www.who.int/csr/disease/coronavirus_infections/case d efinition/en/index.html. Last accessed 10 October 2012.

14. Danielsson $\mathrm{N}$, on behalf of the ECDC Internal Response Team, Catchpole M (2012) Novel coronavirus associated with severe respiratory disease: Case definition and public health measures. Euro Surveill 17: pii=20282. Available online: http://www.eurosurveillance.org/ViewArticle.aspx?ArticleId= 20282. Last accessed 10 October 2012.

15. Al Hajjar S, Al Thawadi S, Al Seraihi A, Al Muhsen S, Imambaccus H (2011) Human metapneumovirus and human coronavirus infection and pathogenicity in Saudi children hospitalized with acute respiratory illness. Ann Saudi Med 31: 523-527.

16. European Centre for Disease Prevention and Control (ECDC) (2012) Communicable Disease Threats Report (Week 18, 29 April-5 May 2012). Stockholm: ECDC. Available from: http://ecdc.europa.eu/en/publications/Publications/CDTR $\% 20$ online \%20version\%204\%20May\%202012.pdf. Last accessed 10 October 2012.

17. Saudi Ministry of Health (2012) http://www.moh.gov.sa/en/Ministry/MediaCenter/News/Page s/News-2012-10-01-002.aspx. Last accessed 10 October 2012.

18. World Health Organization (2012) Health conditions for travellers to Saudi Arabia for the pilgrimage to Mecca (Hajj). Weekly Epidemiological Report 87: 277-288 Available on line at http://www.who.int/wer/2012/wer8730/en/index.html. Last accessed 10 October 2012.

\section{Corresponding author}

Mohammed N. Al-Ahdal, BPharm, PhD

Department of Infection and Immunity

The Research Centre

King Faisal Specialist Hospital and Research Centre

PO Box 3354 (MBC-03), Riyadh 11211, Saudi Arabia

Tel: +96614424581/+96614427867

Fax: +96614424519

E-Mail: ahdal@kfshrc.edu.sa or drahdal@gmail.com

Conflict of interests: No conflict of interests is declared. 